\title{
The Utilization of Compact-Convertible Furniture Module in Studio-Type Apartment in M-Town Residence at Summarecon Serpong
}

\author{
Vina Natalia ${ }^{1}$ Samsu Hendra Siwi ${ }^{1 *}$ Fermanto Lianto $^{1}$ M. B. Susetyarto ${ }^{1}$ \\ ${ }^{I}$ Master of Architecture Department, Faculty of Engineering, Universitas Tarumanagara, Jakarta, Indonesia \\ *Corresponding author.Email: samsus@ft.untar.ac.id
}

\begin{abstract}
The rise of vertical construction in apartments is in the spotlight because it has provided facilities that meet its residents' needs compared to landed houses. Even though it has complete facilities, each unit has a small to large scale room. A unit with a small scale is called a studio, which tends to have a limited area. So the elements of space-fillers such as the form and size of the furniture in the studio unit apartment must accommodate several activities or functions into a particular of furniture. The use of compact, multifunctional, and convertible furniture needs to be utilized considering the unit's limited available space. Compact furniture is multifunctional furniture that is packed close together, neatly, and all components with the required functions have been neatly compacted into a small unit. This study aims to determine the use of compact furniture modules in studio type units in Summarecon's M-Town apartment in Serpong to maximize furniture use in a limited space. The method used is a qualitative descriptive method. Most of the field results implement fixed furniture features in each unit, including studio type units. With space in the studio type units that are very minimalist, multifunctional furniture is needed for efficiency and flexibility in its use. With this research, it is expected to be considered in studio apartment units' interior arrangement to be used as fully as possible.
\end{abstract}

\section{Keywords: Apartment, Furniture, Compact, Convertible, Module}

\section{INTRODUCTION}

Decreasing land for urban housing development has become a common issue, especially in Jakarta City, Indonesia. Land availability for landed housing is increasingly scarce while demand for housing is increasing, so vertical development is in the spotlight. The apartment provides complete facilities and affordable access to technology. Besides that, the apartment is usually built in a strategic area near offices, public transport facilities, shopping centers, etc. It is very easy for residents to reach these areas. The principle of an apartment is a small land that can be used as a residence for many people because the building is developed vertically, and the need for a large area makes the apartment very suitable to be built in the middle of the city [1]. In contrast to landed houses, the area of an apartment unit is limited so that there are units with different space functions combined into one room, one of which is a studio type unit.

Studio type apartments are known for their limited area so that the elements of space-fillers such as the shape and size of the furniture contained in the studio unit apartment must be able to accommodate several activities or functions into particular furniture. Besides being more efficient, the use of space can also produce a better circulation path for residents [2]. In-studio type apartment units, the use of compact, multifunctional, and convertible furniture needs to be utilized considering that the available space on the unit is quite limited. This is so the room with a small area can be used as much as possible accompanied by appropriate furniture.

\section{BACKGROUND}

The Studio type apartment is units that only have one multifunctional space. Space can be used as a sitting room, bedroom, and kitchen, originally open without partition. A separate room is only a bathroom [3]. There are extensive limitations on a simple dwelling so that the utilization of residential spaces is generally done by combining several spaces that have a closeness of function. Based on the main activities of the occupants and the equipment or furniture available in simple dwellings, the space requirements in simple dwellings can be grouped into several main room groups, like terraces, living rooms, family rooms, dining rooms, kitchens, bedrooms, bathrooms, and laundry room [4]. Design to meet the demands of efficiency, comfort, and quality today is the application of modular furniture. Modular furniture is one answer to the problem of human needs in confined spaces. This type of furniture is built-in units that can be assembled to meet space and functional requirements [5]. Modularity refers to organizing 
components into subgroups. The arrangement of one module can consist of several smaller modules. The difference between modular and non-modular variants is perceived complexity, versatility, ease of use, and ease of maintenance. The components are grouped for a reason, either a function or a life cycle, the product shows modularity [6]. The right furniture used in studio type apartments is convertible furniture, which can change shape, function, or character according to the user's needs at that time. Combining several furniture pieces into one by the similarity of activities or functions can minimize the use of furniture in large quantities in a limited area of apartment units [2].

Furniture is described as a physical property that can be converted (changes from one form to another). The flexibility of furniture can be obtained from a piece of furniture by changing the arrangement or adding other pieces without reducing the room's efficiency, aesthetics, and function [7]. Furniture table and chairs can have multiple functions. A multifunctional table can be used as a dining table, work table, and guest table, while a multifunctional chair can be used as a dining chair, work chair, and guest chair to provide comfort for residents of the apartment [9]. Multifunctional furniture can be modular or can be folded or knocked down. The type of furniture that is designed is multifunctional with a modular system so that the furniture is easy to use anywhere and anytime (flexible), especially in the design of residences and apartments [10]. The benefits of transformable furniture in apartment units, especially small scale, are: (1) save space. Which when finished used or will not be used for a while, each piece of furniture can be folded into smaller or closer to the wall, which effectively provides additional space for other purposes. This can be done anytime quickly and easily without the need for extra time and effort; (2) creative use by having more than one function; (3) freedom in variety, for example, making a multifunctional bed with lots of spare cabinets underneath [11].

\section{METHODS}

The research method used is a qualitative method presented descriptively. The research focus is in the form of a studio type apartment unit in Tower Carmel, M-Town Residence Summarecon Serpong. This study aims to determine the use of compact furniture modules in studio type units at the MTown Summarecon apartment in Serpong so that they can maximize the use of furniture in limited space. The field findings are then analyzed by the theory from the literature review so that the final results are obtained as conclusions and suggestions [12].

In this case, the analysis was carried out in the type studio unit room. This is an analysis of space and user needs, then using suitable furniture modules according to users in general with various alternative compact furniture modules assisted by the theoretical references obtained.

\section{FINDINGS AND DISCUSSIONS}

Flexural the apartment was built with complete supporting facilities that have been provided to support and facilitate residents in one location. M-Town Residence in Serpong was built by combining residential, office space, and commercial areas with integrated ease of access. The close distance between residences with offices and commercial areas will increase the efficiency of apartment dwellers' time and mobility [13]. In the apartment unit as a place to support residents' lives, there are studio type units with the limited area while the room is required to have a double function.

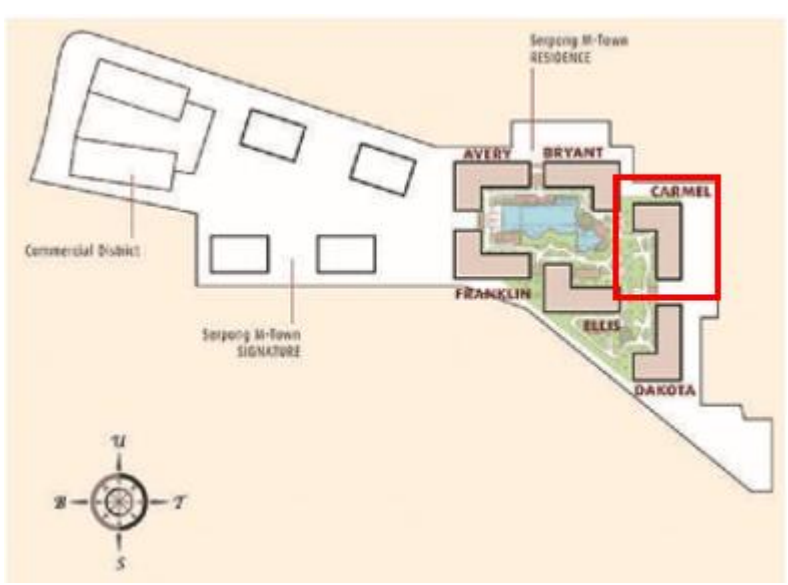

Figure 1. Plan of M-Town Residence Serpong Source: [13]

At M-Town Residence Serpong consists of 6 towers, namely Avery, Bryant, Carmel, Dakota, Ellis, and Franklin, with the same typical units, like studio type and onebedroom two bedrooms, and three bedrooms. The focus of this research is in the form of a studio type unit in the Carmel Tower. The studio type unit was chosen because it is a unit with limited space and is quite narrow when there is a placement of furniture that is less efficient and takes up much space.

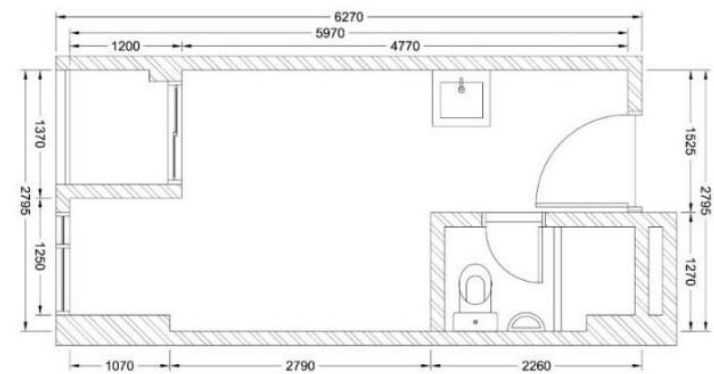

Figure 2. Layout Unit Studio Type Carmel Tower MTown Residence Serpong (non-furnish) Source: [13]

From the design side, land limitations do not allow a room to be made for one function, so in terms of space utilization, it must be multifunctional. One room that is used together 
is realized with a compact design. Layout and selection of contents must also be efficient, innovative, and smart. Regarding furniture, it is not recommended to buy finished products, if buying ready-made furniture, it is possible to use loose furniture (removable furniture or not per set) with a multifunctional design [14]. M-Town Residence Serpong with studio type units is provided in both furnish and nonfurnish conditions. In-studio type units that have not been filled with furniture, only a bathroom, washing or sink area, and balcony are provided. This laying should not be moved in accordance with the policy of apartments or vertical houses in general because it will have an impact on the overall utility of the apartment. Thus, laying on the service area has been formed from the apartment.

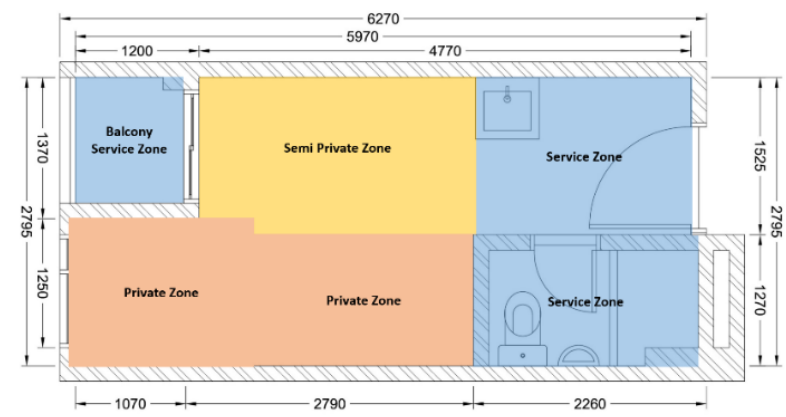

Figure 3. Zoning in Studio Type Units Carmel Tower M-Town Residence Serpong

Source: Authors, 2020

Areas in a building can be divided into several main groups, namely public zones, semi-private zone; private zone; very private zone; service zone; circulation zone [15]. Basic activities that must be accommodated in a simple house are sleeping, sitting, eating, cooking, and MCK (eating, washing, toilet) [16]. In M-Town Residence Serpong with studio type units, zoning is divided into four parts, namely: service zones, sleep zones, relaxation zones, and work or study zones. The zones are divided according to the basic activities of users in general in a dwelling.

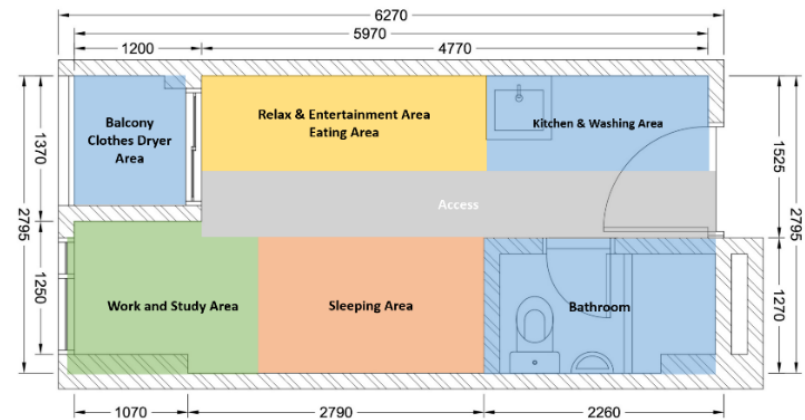

Figure 4. Area space in Studio Type Units Carmel Tower M-Town Residence Serpong

Source: Authors, 2020

Each space involves certain activities. Therefore the role of each space is also determined by most of the occupants' activity needs. Public spaces for various activities are categorized into 6: sharing or public spaces; workspace; study room; eating and drinking areas; recreation room; and service room [15]. A residential area has consisted of 6 rooms, namely: bedroom, bathroom, kitchen, lounge, equipment room, and space or circulation [17]. At M-Town Residence Serpong studio type units are divided into six areas, namely: kitchen and laundry areas; bathroom area; sleeping area; work or study area; relaxing, entertainment, eating and drinking areas; balcony and clothesline area; also access area. A place needs a lot of fixed furniture that takes up more space and not circulation. Flexibility in housing can be achieved and free up space by applying multifunctional furniture [7].

The use of every corner of the house is presented with furniture. That has multiple functions, which occupy an area to be maximized by combining the function of furniture so that the existing area is not only used for one activity but can be used for other activities when the furniture is no longer used [18]. Multiple functions occur in these areas due to limited space available. Specifically, the relaxing area is the most flexible because it can be adapted to the needs of the occupants. In addition to an area for active activity, a passive area such as a storage area is also needed. In the studio-type unit furniture layout (Figure 4), there is no apparent application of the item storage area due to the limited area available, so the storage area must be combined with other furniture. This can be applied by making the room multifunctional and flexible, supported by the use of compact furniture. The more furniture functions are, the better by keeping in mind the ease of use and the affordable price. However, it must be admitted that design investments with higher prices can result in more efficient, maximum, and representative space utilization [14].

The selection of geometric shapes in the form of a square is intended to utilize every corner that is available in the apartment space so that residents will have more free space in the room [18. the arrangement or laying of furniture contents is rather close to the wall to create circulation in the room's middle. Each side of the room is easily accessible without any obstacles. The furniture applied is compact and has a double function with a square geometry so that every part can be utilized. The use of vertical space is also applied to minimize the use of horizontal space, which tends to make full and narrow space. The following is an example of an M-Town Residence apartment layout with studio type units along with a recommendation of a double function compact furniture:

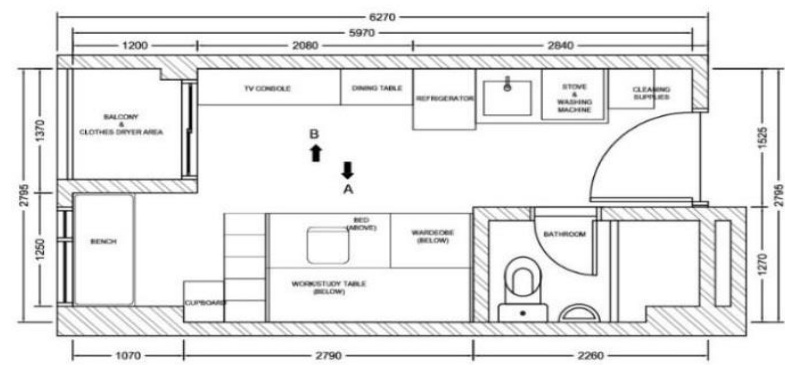

Figure 5. Alternative Recommendation Layout 1

Source: Authors, 2020 
An alternative recommendation layout 1 (Figure 5) there is a combination of bed furniture, work or study desks, wardrobe, storage stairs, and storage cabinets. his makes the unit have plenty of storage space, which also does not interfere and makes narrow circulation.

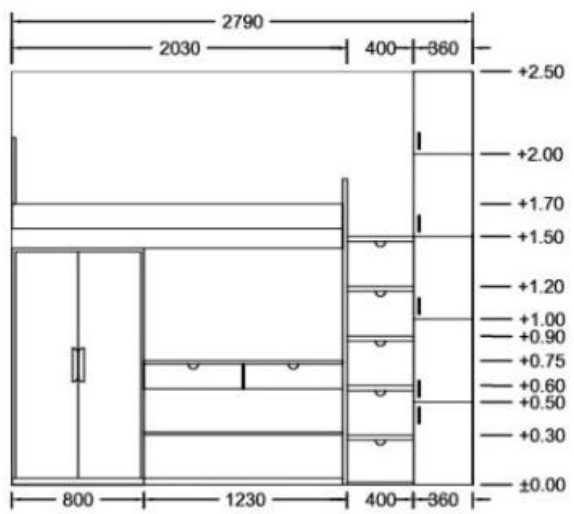

Figure 6. View A

Source: Authors, 2020

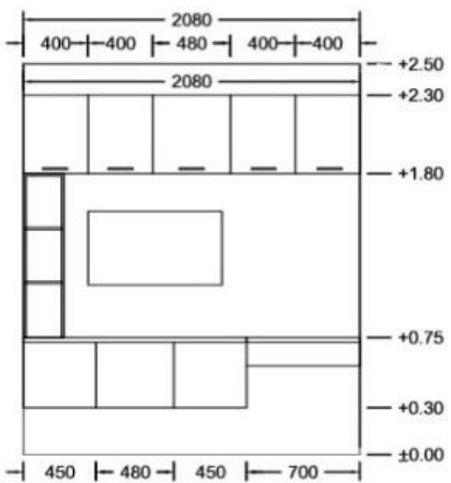

Figure 7. View B

Source: Authors, 2020

In view A (Figure 6) the bed is applied above with access via a ladder. Which also functions as a storage area. There is a work or study desk at the bottom of the bed combined with a fairly small wardrobe. Whereas in view B (Figure 6) the leisure area combines the TV Console with a table for eating and drinking. The storage area utilizes a vertical area so that it is more effective and neat in its placement.

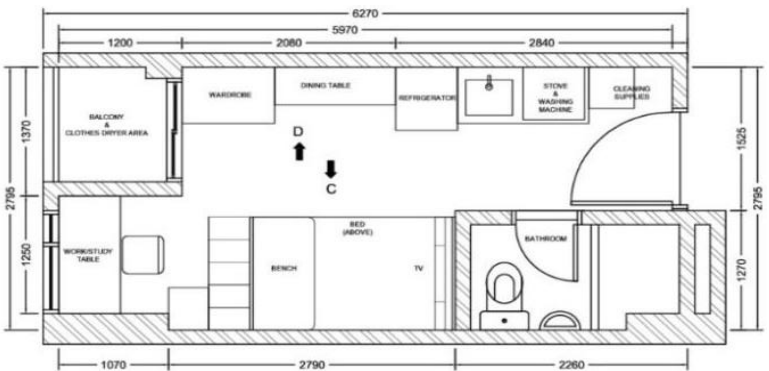

Figure 8. Alternative Recommendation Layout 2

Source: Authors, 2020
An alternative recommendation layout, 2 (Figure 7) is in the form of a combination of bed furniture, mini TV Console, bench, storage stairs, and storage cabinets. This is a combination where the sleeping area is above, and the entertainment area is below. So the sleeping area and entertainment area can still be put together but not interfere with each other.

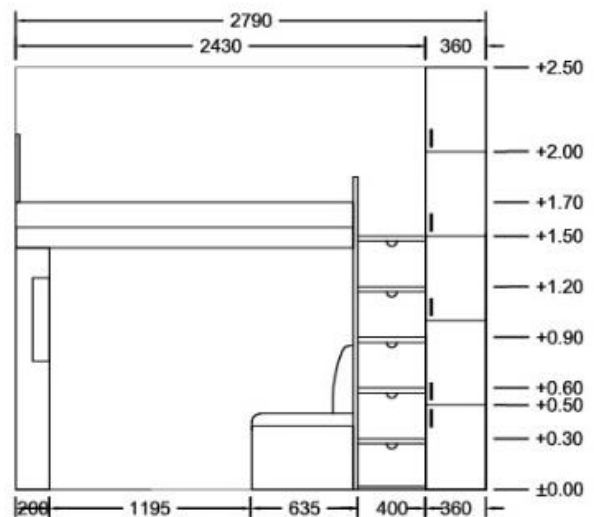

Figure 9. View C

Source: Authors, 2020

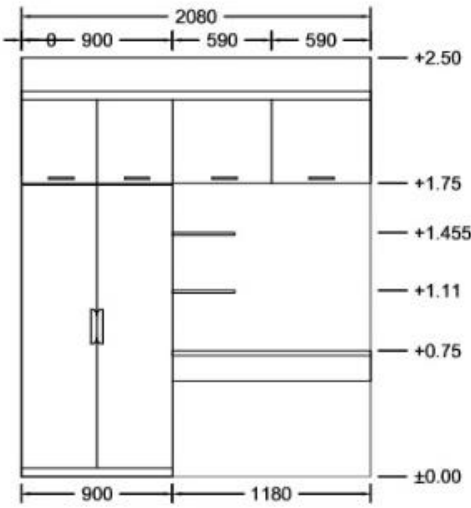

Figure 10. View D

Source: Authors, 2020

In view $\mathrm{C}$ (Figure 8), the bed is still applied above with access via a ladder, which also functions as a storage area. There is an entertainment area at the bottom of the bed in the form of a mini TV Console and bench that can also be used as a place to relax or eat and drink. While in view D (Figure 8), this area is used for storage in the form of a large enough wardrobe and several upper cabinets, also combined with a table (can be folded when not used anymore) that can function as a place to put goods or become a dining area in accordance with user requirements. This area is dedicated to storage so that limited units can also store a lot of things without interrupting circulation and look messy. 


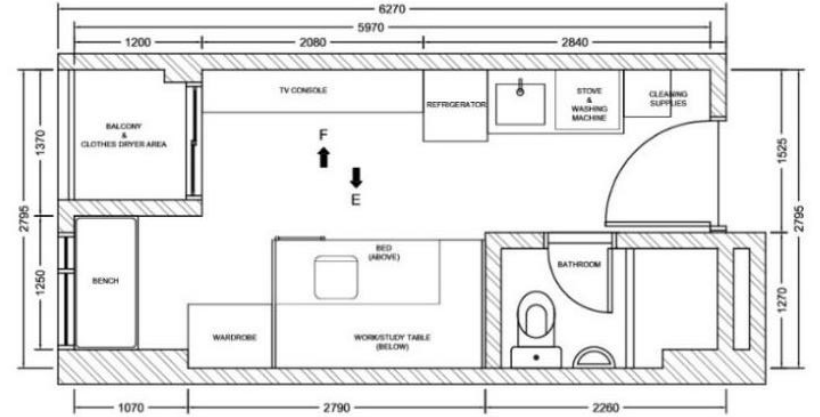

Figure 11. Alternative Recommendation Layout 3 Source: Authors, 2020

An alternative recommendation layout 3 (Figure 9) the combination of furniture in the form of a bed, work or study table, and wardrobe. This is a combination where the sleeping area is at the top, and the work or study area is at the bottom. In contrast to alternative 1 (Figure 5) and alternative 2 (Figure 7), which uses storage stairs as access to the sleeping area, alternative layout 3 (Figure 9) only applies a single ladder (optionally made to shift or not as needed).

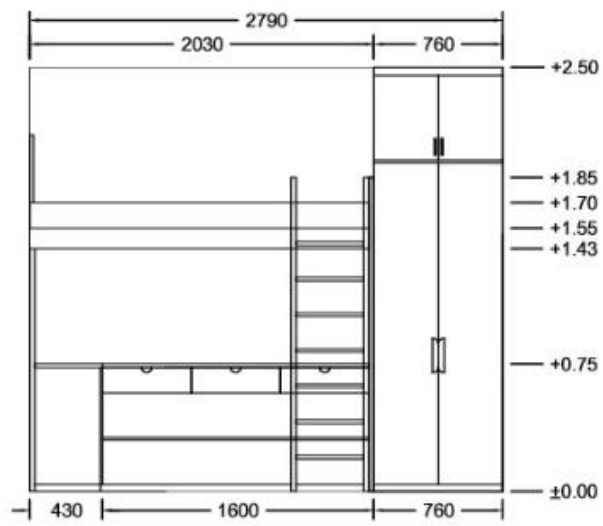

Figure 12. View E

Source: Authors, 2020

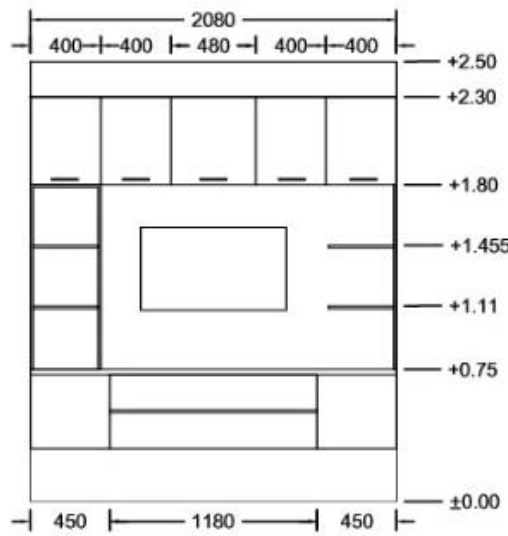

Figure 13. View $\mathrm{F}$

Source: Authors, 2020
In view $\mathrm{E}$ (Figure 10), the fixed bed is applied above with access via a single ladder. At the bottom of the bed, there is an area that is entirely used as a place to work/study. There is a large enough wardrobe for the storage area. While in view $\mathrm{F}$ (Figure 10), this area is as a whole function as an entertainment area with supporting furniture in the form of a TV console and shelves, which are also combined with the upper cabinet as a storage area for goods. The use of modular systems uses an efficient production process, saving labor, time, costs, and optimal absorption of raw materials. In addition, the modular system can also increase the selling value and purchasing power of the people with a more affordable product price.

The design of furniture products uses a knockdown construction system that allows users to install independently or dismantle pairs according to space [19]. Of the three furniture design alternatives above, each area does not have to be arranged with a rigid arrangement of furniture and takes up a lot of space, combining and being useful with different functions without being interrupted. The application of furniture in a vertical area is also very helpful in the arrangement, especially for storage because the area is at the top and rarely touched. Besides being more efficient and not disrupting circulation, compact furniture can also make the room look unique with its visual combination and not boring. Formation and composition development can still be processed to adjust the market needs in accommodating its inhabitants' activities to be more optimal and based on the property owner's budget.

\section{CONCLUSION}

In contrast to landed houses that provide a lot of space, apartments with studio type units have a limited area, so that the application of unorganized furniture can make the room more cramped and cramped due to goods that are piled up. The compact furniture module is very useful for residences with limited areas such as apartments with studio type units. The longer a person inhabits a place, the more certain things will be. In order not to become a pile of goods that, in addition to damaging the visual space, also interferes with circulation, multifunctional furniture can be applied.

The use of vertical areas is also very helpful in getting around the limited space. Area arrangement can also be more flexible and do not have to be fixed in one area, such as a sleeping area combined with an entertainment area or work or study area without interfering with each other. Combining the area with compact furniture can be a solution for a room with a small-scale occupancy that guides many functions. The room can be used as much as possible, and pay attention to ease of use and affordable prices. The formation of compact furniture can vary according to market needs and budget considerations from property owners. In this case, the design investment is higher but can result in more efficient and maximum space utilization. 


\section{ACKNOWLEDGMENT}

This paper was composed because of help and support from various parties, for that, a thankyou was conveyed especially to M-Town Residence Summarecon Serpong which has provided information about the apartment to researchers.

\section{REFERENCES}

[1] A. N. Muharam, Menata Furnitur di Ruangan Sempit, Indonesia: Griya Kreasi, 2009.

[2] A. D. Cahyaningtyas and S. Rahardjo, "Penggunaan Konsep Space Saving untuk Apartemen Tipe Studio di Kota Bandung," Jurnal Idealog, vol. 1 No. 2, pp. 178192, Agustus 2016.

[3] C. A. Lumakso, A. P. Setiawan and Y. Santoso, "Perancangan Meja Multifungsi untuk Mahasiswa Desain Interior di Apartemen Tipe Studio," Jurnal INTRA, vol. 4 No. 2, pp. 585-597, 2016.

[4] R. Widyahantari, M. N. F. Alfata and Y. Hermawan, "Simulasi Ruang Gerak Dalam Hunian Sederhana Berdasarkan Antropometri Manusia Indonesia (Menuju Standarisasi Perencanaan dan Perancangan Hunian Sederhana yang Ergonomis)," Jurnal Standarisasi, vol. 15, pp. 36-46, Maret 2013.

[5] BureauShip, "Bureau of Ships Journal," Bureau of Ships Journal, vol. 4 No. 9, January 1956.

[6] R. J. Smith, "The Impact of Modular Design on Product Use and Maintenance," Georgia Institute of Technology, 2009.

[7] O. Q. Abdulpader, O. A. Sabah and H. S. Abdullah, "Impact of Flexibility Principle on The Efficiency of Interior Design," International Transaction Journal of Engineering, Management, \& Applied Sciences \& Technologies, 2014.

[8] T. S. Reinhard and T. Hidayat, "Desain Furnitur Meja dan Kursi Multifungsi untuk Apartemen Tipe Studio," Jurnal Sains dan Seni Pomits, Vol. 3 No.1, 2014.

[9] M. Wibowo and C. C. Kwan, "User Centered Design untuk Mebel Multifungsi Fasilitas Olahraga Balita," Jurnal Saintek, vol. 13 No. 2, pp. 139-153, Desember 2016.

[10] The Loggia, "Manfaat Transformable Furniture di Apartemen Bergaya Jepang The Loggia," 16 Agustus 2019. [Online]. Available: http://www.theloggia.co.id/ content/artikel/manfaat-transformable-furniture-diapartemen-bergaya-jepang-the-loggia. [Accessed 14 Mei 2020].

[11] P. D. Sugiono, Metode Penelitian: Kuantitatif, Kualitatif, dan R\&D, Bandung: Alfabeta, 2017.

[12] Summarecon, "Serpong M-Town," 2016. [Online]. Available: https://www.summareconserpong.com/ project/other-projects/serpong-m-town. [Accessed 12 Mei 2020].

[13] J. E. Widyartanti, "Tak Hanya Desain, Pola Hidup Ini Bikin Rumah Mungil Nyaman Ditinggali," 24 Oktober 2019. [Online]. Available: https://idea.grid.id/ $\mathrm{read} / 091895835 /$ tak-hanya-desain-pola-hidup-ini-bikinrumah-mungil-nyaman-ditinggali? page $=4$. [Accessed 14 Mei 2020].

[14] P. Suptandar, Pengantar Mata Kuliah Desain Interior: Untuk Arsitek dan Desainer, Jakarta: Universitas Trisakti, 1995.

[15] M. S. Suryo, "Analisa Kebutuhan Luas Minimal Pada Rumah Sederhana Tapak di Indonesia," Jurnal Permukiman, vol. 12, pp. 116-123, 2017.

[16] M. Mitton and C. Nystuen, Residential Interior Design: A Guide To Planning Space, Canada: John Wiley \& Sons. Inc, 2007.

[17] P. E. Cristi and Y. Kusumarini, "Perancangan Interior Modular Pada Residential Space Tipe Studio," Jurnal Intra, vol. 2 No. 2, pp. 189-196, 2014.

[18] H. Goutama, G. Mulyono and P. F. Nilasari, "Perancangan Produk Interior Modular Multifungsi Berbasis Material Kayu Olahan," Jurnal Intra, vol. 6 No. 2, pp. 69-77, 2018.

[19] C. Wijaya, Y. Kusumarini and F. P. Suprobo, "Perancangan Portable Folding Furniture untuk Interior Apartemen Tipe Studio," Jurnal INTRA, vol. 3 No. 2, pp. 9-17, 2015. 